\title{
EXPRESSION OF TRANSFORMING GROWTH FACTOR ALPHA BAMHI AND RSAI GENE VARIANTS ASSOCIATED WITH NON-SYNDROMIC CLEFT PALATE OF INDONESIAN SUBJECTS USING POLYMERASE CHAIN REACTION METHOD
}

\author{
ANI MELANI MASKOEN ${ }^{1}$, SASKIA L NASROEN ${ }^{2,3}$, PRIMA NANDA FAUZIAH ${ }^{4}$, EKY SETIAWAN SOERIA SOEMANTRI ${ }^{5}$, \\ BASRI A GANI ${ }^{6 *}$
}

${ }^{1}$ Department of Oral Biology, Faculty of Dentistry, Universitas Padjadjaran and Health Study Unit of Hasan Sadikin Hospital, Bandung, Indonesia. ${ }^{2}$ Department of Oral and Maxillofacial Surgery, Faculty of Medicine, Universitas Padjadjaran, Bandung, Indonesia. ${ }^{3}$ Dentistry Program Study, Faculty of Medicine, Universitas Jenderal Achmad Yani Cimahi, Bandung, Indonesia. ${ }^{4}$ Laboratory of Molecular Genetics, Faculty of Medicine, Universitas Padjadjaran, Bandung, Indonesia. ${ }^{5}$ Department of Orthodontic, Faculty of Dentistry, Universitas Padjadjaran, Bandung, Indonesia. ${ }^{6}$ Department of Oral Biology, Dentistry Faculty, Syiah Kuala University, Banda Aceh, Indonesia. Email: basriunoe@gmail.com

Received: 12 December 2017, Revised and Accepted: 15 January 2018

\section{ABSTRACT}

Objective: This study aimed to detect and analyze transforming growth factor alpha (TGFA) BamHI and RsaI gene variants which associated with the risk factor of non-syndromic cleft palate only (NS CPO) of Indonesian subject.

Methods: This was case-control study using samples from 32 NS CPO subjects and 28 control subjects. DNA was extracted from venous blood, and the TGFA gene was amplified using polymerase chain reaction technique, then digestion product from TaqI and RsaI restriction enzyme was evaluated. Statistical analysis to determine significant differences of gene variant frequency among NS CPO subject and control was $\chi^{2}$. The odds ratio (OR) was used to determine a risk factor of NS CPO.

Results: The study results showed that the TGFA BamHI gene variant was not identified in NS CPO among Indonesian but TGFA RsaI gene variant was identified. The frequency of TT/B1B1 homozygous mutant genotype was $80.0 \%$ in NS CPO subjects and 20.0\% in control subjects (OR=3.857; $95 \%$ confidence interval $=0.405-36.749$ ).

Conclusion: TGFA RsaI gene can be considered a risk factor of NS CPO compared TGFA BamH1 gene of Indonesian subjects.

Keywords: Cleft palate, Non-syndromic, Gene variant, Transforming growth factor alpha BamHI, Transforming growth factor alpha RsaI.

(C) 2018 The Authors. Published by Innovare Academic Sciences Pvt Ltd. This is an open access article under the CC BY license (http://creativecommons. org/licenses/by/4. 0/) DOI: http://dx.doi.org/10.22159/ajpcr.2018.v11i4.24242

\section{INTRODUCTION}

Orofacial clefts are defects of birth that caused by the disorder of anatomical, genetical, and embryological. They are subdivided into those affecting the lip and/or palate/primary palate (CL/P) and those involving the palate only/secondary palate (cleft palate only [CPO]) which has the distinct embryologic and pathophysiologic mechanisms of both types [1]. According to the physical and developmental anomalies, clefts categorized into syndromic and non-syndromic (NS) unto $70 \% \mathrm{CL} / \mathrm{P}$ and $50 \%$ CPO [2]. NS CPO reported one of the most common congenital malformations that affect between 1 in 1000 and 2500 live births worldwide [3].

The formation of the secondary palate (palatogenesis) in mammals involves the orchestration of several processes to produce the correct separation of the oral and nasal cavities. Failure of palatogenesis results in cleft palate, one of the most common birth defects in humans [4]. Genetic and developmental differences have suggested that the mechanisms underlying $\mathrm{CL} / \mathrm{P}$ and $\mathrm{CPO}$ are different from the formation of the primary palate and secondary palate $[1,5]$. The sex distribution in the two is different, for example, with $\mathrm{CL} / \mathrm{P}$ being more common in males and CPO more commonly found in females. It is likely, however, that some common signals may affect the formation of both the primary and secondary palate, even though they are embryo-logically distinct [6]. The secondary palate in human begins to develop early in the $6^{\text {th }}$ week from the two palatal shelves, which extend from internal aspects of the maxillary prominences [7].
The most factors of cleft palate have consumed the drug during pregnancy [8]. Dexamethasone is one of the drugs reported as the risk factor of cleft lip with or without cleft palate as well as other subsequent side effects on the child [9]. The other factors are gene mutation, including transcription factors, growth factor receptors, extracellular matrix components, and cell surface adhesion molecules also decreased malonylcarnitine [10]. Palatal fusion itself appears to be driven by several cell adhesion molecules, including nectin-1, desmosomes and Type IX collagen, and growth factors, such as transforming growth factor $\beta 3$ (TGF $\beta 3$ ) and TGF alpha (TGFA) were important to gene mutation in cleft palate cases [11]. TGFA was mapped the chromosome $2 \mathrm{p} 13$, comprises 80 kilobases of genomic DNA, and consists of six exons, it was selected as the candidate gene of $\mathrm{CL} / \mathrm{P}$, because its expression in palatal tissue in culture and its presence at high levels in epithelial tissue of medial edge of the palatal shelves at the time of shelf fusion [12]. TGFA alleles and NS CL/P were specifically in a Caucasian, US population, and Chilean Caucasian-Mongoloid, Japanese, and Vietnamese populations [13].

In general, TGFA has three genes of polymorphisms (RsaI, and TaqI in intron 5, and BamHI in an exon. These genes investigated a susceptibility of CL/P [14], nevertheless it is debatable and contradictory [12]. Qian (1993) was reported who the evidence for TGFA TaqI gene variant association with NS CPO was shown in a Caucasian population and a West Bengali Indian population [13,14]. Our previous studied (manuscript in preparation) showed that TGFa/Taq1 gene variant can be considered to be the risk factor associated with NS CPO development 
in Indonesian patients that was associated with increased risk of NS CPO. Therefore, this research aimed to assess the TGFA BamHI and TGFA RsaI gene variants and the risk of NS CPO of Indonesian.

\section{MATERIALS AND METHODS}

\section{Material}

This research has approved with the ethical clearance No.395/UN6. C1.3.2/KEPK/PN/2016 issued by Faculty of Medicine, University of Padjadjaran, Bandung, Indonesia. This study was used to 32 NS CPO subjects and 28 controls without family history of craniofacial clefts, both samples were from deutero-malay race as the majority of race among Indonesian, and based on the molecular epidemiology of casecontrol study which is done in Molecular Genetic Laboratory, Faculty of Medicine Universitas Padjadjaran in Bandung, West Java, Indonesia. Venous blood samples were collected along with informed consent.

\section{DNA extraction and polymerase chain reaction (PCR)}

DNA extraction and running PCR were taken kits of Kapa Biosystems, Wilmington, MA, USA. DNA from venous blood was then extracted using DNA isolation standard method by Vemuri et al. (2016) and Bachtiar and Bachtiar (2017) [15,16]. Furthermore, TGFA BamHI and TGFA $R s a$ I fragments were amplified with PCR that adapted by Omran et al. (2016) [17]

PCR for TGFA BamHI gene variant was performed using the primers of Forward/AP3: 5'-ACAGATGGCGGAACGAGAGGT-3' and reverse/AP4: 5'-CTAAAGGGCAAGGAAACACAG-3'. PCR for TGFA Rsal gene variant was performed using the primers of forward/AP5: 5'-TGCCTCACCACGACAGACACA-3' and reverse/ AP6: 5'-TGAATAACCCCAAGCAGACGG-3'. The PCR analyses have four cycles with temperatures $93^{\circ} \mathrm{C}, 1 \mathrm{~min}$, annealing $57^{\circ} \mathrm{C}$ for $\mathrm{AP} 3 / \mathrm{AP} 4$ primer; $58^{\circ} \mathrm{C}$ for AP5/AP6 primer; $1 \mathrm{~min}$ of each, extension $72^{\circ} \mathrm{C}, 1 \mathrm{~min}$ and PCR were running at 30 cycles $[7,18]$. Analysis for gene variant of TGFA BamHI and TGFA Rsa1 has been run by PCR - restriction fragment length polymorphism (RFLP) using the BamHI and RsaI restriction enzymes, respectively RFLP for TGFA BamHI and TGFA RsaI gene variant $[16,19]$. PCR products from TGFA gene were digested with BamHI and $R s a \mathrm{I}$ restriction enzymes at $37^{\circ} \mathrm{C}$. PCR products were separated on a $2 \%$ agarose gel containing ethidium bromide and then visualized with an ultraviolet trans-illuminator [15-17].

\section{Statistical analysis}

A statistical analysis which was used to determine significantly $(\mathrm{p}<0.05)$ of differences from sequence variants frequency among NS CPO subject and control subject was $\chi^{2}$. The odds ratio (OR) was used to determine a risk factor of NS CPO.

\section{RESULTS AND DISCUSSION}

\section{Statistical analysis}

Statistical analysis of TGFA BamHI and TGFA RsaI gene variants was shown in Table 1. Whereas statistical analysis of genotype frequency of normal homozygous of CC genotype, the heterozygous mutant of CT genotype and a homozygous mutant of TT genotype shown in Table 2 . In TGFA Rsal gene variant from this study, the frequency of homozygous mutant of TT genotype $(\mathrm{OR}=3,857 ; 95 \%$ confidence interval $[\mathrm{CI}]=0.405-$ 36.749 ) will increase the risk of NS CPO for 3857 times compared with control subjects.

Cleft of secondary palate in the absence of a cleft lip (CPO) is etiologically distinct from the cleft lip with or without cleft palate (CL/P) on the basis of epidemiologic data, separate patterns of the risks of recurrence, and embryonic palate and lip formation [7]. The development of the secondary palate, or roof of the mouth, involves proliferation and differentiation of palatal epithelial cells as well as programmed cell death. The occurrence of cell death within the medial epithelial lamina between the fusing palatal processes assists in the removal of the medial palatal epithelium [18]. During the initial stage of the fusion process, the epithelial covering the tip of each palatal shelf (MEE) that surrounded by mesenchyme then undergoes dissolution and leaving confluent mesenchyme in the forming palate adhere to form a midline epithelial seam (MES) [4]. The MES disappear through the combination of programmed cell death, epithelial-mesenchymal transformation, and migration to the oral and nasal palatal epithelial failure of any of these processes can result in the isolated cleft palate [20].

\section{Expression of TGFA BamH1 and TGFA RsaI genes}

The initial PCR product of TGFA BamH1 gene variant showed DNA band segment with the size of 434 base pairs (bp) and TGFA Rsal gene variant size of 657 bp. (Fig. 1). TGFA BamH1 gene variant means that there is substituting nucleotide of A (A2) into C (A1). After obtaining the initial PCR products of the segment of TGFA BamH1 gene variant, samples were then digested with the specific restriction enzyme BamH1 [21]. After digestion, the 434 bp products were completely digested with one restriction sites to create two specific bands of 313 and $121 \mathrm{bp}$ for homozygous normal of AA (A2A2) genotype feature as can be seen in this present study (Fig. 2), for heterozygous mutant of AC (A1A2) genotype feature it will show three specific bands of 434, 313, and $121 \mathrm{bp}$ and for the homozygous mutant of CC (A1A1) genotype feature. In this study, we only found the feature of AA (A2A2) genotype from all subjects.

TGFA is a secretion protein that binds to the epidermal growth factor (EGF) receptor and is situated in the palate epithelium during secondary palate closing. GFA may function as a normal embryonic version of EGF-related growth factor [4]. EGF/TGFA and glucocorticoids are believed to regulate the proliferation and differentiation of palatal epithelial cells both in vitro and in vivo. Moreover, the continued presence of EGF inhibits the fusion process; TGFA is likely to have similar effects. These biological studies suggest that mutations in the TGFA gene might contribute to the development of CL/P, especially for those mutations that affect the timing of the tissue-specific expression of this gene [22].

TGFA was chosen as a candidate gene in the preliminary association studies of CL/P because it is expressed in palatal tissue in culture. In palatal cultures, TGFA promotes synthesis of extracellular matrix and mesenchyme cell migration, thereby ensuring the strength of the fused palate [21]. It subsequently revealed that TGFA was present at high levels in epithelial tissue of the medial edge of the palatal

Table 1: Allelic frequency of $\mathrm{C}$ and T nucleotide of TGFA RsaI gene in NS CPO

\begin{tabular}{|c|c|c|c|c|c|c|}
\hline \multirow[t]{2}{*}{ Allele } & \multicolumn{2}{|c|}{ Subjects } & \multirow[t]{2}{*}{$\chi^{2}$} & \multirow[t]{2}{*}{$\mathbf{p}$} & \multirow[t]{2}{*}{ OR } & \multirow[t]{2}{*}{ CI 95\% } \\
\hline & $\begin{array}{l}\text { NS } \\
\text { CPO }\end{array}$ & Control & & & & \\
\hline $\mathrm{Cn}$ & 29 & 27 & 0.099 & $\mathrm{p}>0,05$ & 1.164 & $0.453-2.989$ \\
\hline$\%$ & 70.7 & 67.5 & & & & \\
\hline $\mathrm{Tn}$ & 12 & 13 & & & & \\
\hline$\%$ & 9.3 & 32.5 & & & & \\
\hline
\end{tabular}

C allele: Wild type allele, T allele: Mutant allele, $\mathrm{P}$ value based on hardy Weinberg proportion. NS CPO: Non-syndromic cleft palate only, OR: Odds ratio, CI: confidence interval, TGFA: Transforming growth factor alpha

Table 2: Genotype frequency of C and T nucleotide of TGFA RsaI gene of NS CPO

\begin{tabular}{lllll}
\hline \multirow{2}{*}{ Genotype } & Subjects & & \multirow{2}{*}{$\chi^{2}$} & p \\
\cline { 2 - 3 } & NS CPO (\%) & Control (\%) & & \\
\hline CC n & 12 & 13 & 1.068 & $\mathrm{p}>0.05$ \\
$\%$ & $37.5 \%$ & $46.4 \%$ & & \\
CT n & 17 & 14 & & \\
$\%$ & $53.1 \%$ & $50.0 \%$ & & \\
\hline
\end{tabular}

CC: Homozygous normal genotype, CT: Heterozygous mutant genotype. NS CPO: Non-syndromic cleft palate only, TGFA: Transforming growth factor alpha 
shelves at the time of shelf fusion in the secondary palate which means the defect on the secondary palate will bring it into CPO [23]. Previous studies on TGFA have focused on $\mathrm{CL} / \mathrm{P}$, while the present study focused on CPO cases alone, based on the role of TGFA in palatal shelves fusion.

TGFA BamHI and TaqI polymorphisms are involved in oral cleft. Their results suggest that TGFA gene or adjacent DNA sequences may contribute to the development of a portion of cases with CL/P $[22,24]$. Ebaidar reported that the three variations of TGFA (BamHI, TaqI, and RsaI) in a British population with $\mathrm{CL} / \mathrm{P}$, and they found a significant association between the TaqI polymorphism and occurrence of cleft [12] Stoll (1993) detected a significant association with BamHI and not with TaqI in a French population of Alsatian ancestry with CL/P. They concluded that TGFA may be a modifier gene, not a major gene that may play a role in the development of bilateral cleft in some individuals [25]. Chenevix-Trench (1991) studied the two polymorphisms of TGFA in unrelated Australians with $\mathrm{CL} / \mathrm{P}$, and a significant association between the TGFA TaqI and BamHI polymorphism and CL/P was confirmed [26].

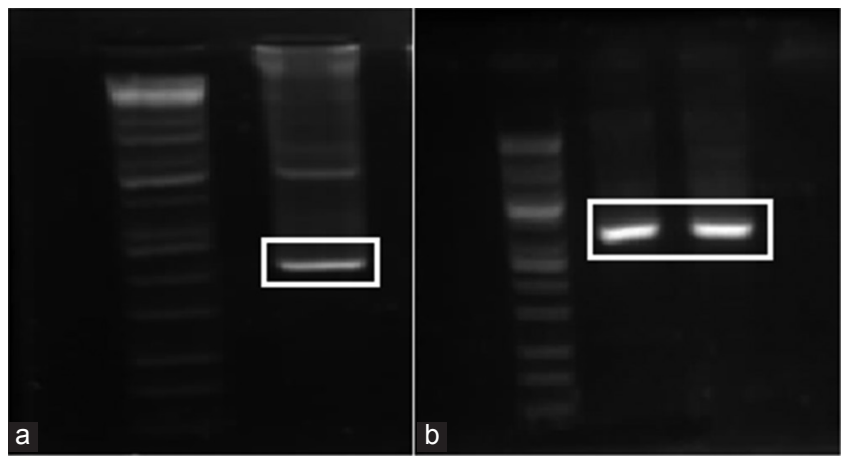

Fig. 1: Initial polymerase chain reaction product (a) Transforming growth factor alpha (TGFA) BamH1 gene variant of 434 bp and (b) TGFA RsaI gene variants of 657 bp

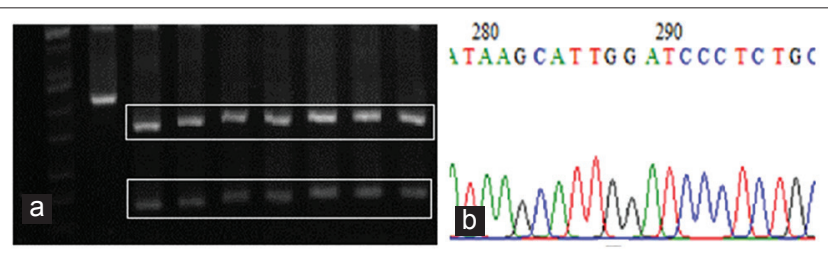

Fig. 2: (a) Polymerase chain reaction products of TGFA BamH1 gene after restriction with BamHI. Line 1.100 bp ladder Line

3-9. The bands in the electrophoresis appearance show digested product of $\mathrm{BamHI}$ restriction enzyme ( 2 bands at 313 and 121 bp), which indicates normal homozygous l genotype AA (A2A2). (b) Sequencing result from TGFA BamH1 gene variant to confirm restriction site of $\mathrm{BamHI}$. The arrow show A2A2 (base of A) homozygous normal genotype
Shiang et al. (1993) reported that found TGFA possibly playing a role in a significant number of cases of NS CPO [27].

The TGFA RsaI gene variant, after digestion of RsaI restriction enzyme, the 657 bp products were completely digested with one restriction sites to create two specific bands of 373 and $284 \mathrm{bp}$ for homozygous normal of CC (B2B2) genotype feature (Fig. 3), for heterozygous mutant of CT (B1B2) genotype feature it will show three specific bands of 657, 373, and 284 bp (Fig. 3) and for homozygous mutant of TT (B1B1) genotype feature, the initial PCR products of 657 bp will not be restricted by RsaI.

The role of TGFA in lip and palate development has been evaluated in different populations with different results means that different phenotypes of $\mathrm{CL} / \mathrm{P}$ may associate with different gene variants of TGFA which include three common polymorphisms or gene variants of the TGFA gene (TGFA RsaI, TGFA TaqI in intron 5, and TGFA BamHI in exon) [27]. In this study, we perform to be more specific in other CL/P phenotype that is focusing on CPO phenotype to be associated with TGFA BamHI and TGFA RsaI gene variants [12].

The TGFA gene shows RFLPs when treated with BamHI and RsaI restriction enzymes and creates TGFA BamHI in exon 6 and TGFA RsaI in intron 5 gene variants [28]. In this study, we performed to examine whether the TGFA BamHI (rs11466297 A/C) and RsaI (rs3732248 C/T) gene variants are associated with the increased risk of NS CPO among Indonesian patients including 32 NS CPO patients and 28 controls. Our results showed that TGFA BamHI polymorphism was not associated with the NS CPO in Indonesian population between the case and control groups, as all subjects showed no C (A1) mutant allele. In contrast, it was a difference in the allele and genotype frequencies of the TGFA RsaI which was found between the case and control groups. In TGFA RsaI, the frequency of the T (B1) mutant allele in the patients $(57.1 \%)$ was higher than that of the control group (42.9\%), the frequency of the RsaI homozygous mutant of TT (B1B1) genotype in the patients $(80,0 \%)$ was significantly higher than that of the control group (20.0\%), and the OR was 3,857; 95\% CI=0.40536.749 , and this result suggests that the TGFA RsaI may be a risk factor for NS CPO among Indonesian patients.

\section{CONCLUSION}

Finally, it can be concluded that TGFA RsaI can be considered a risk factor of NS CPO among Indonesian subjects compared TGFA BamH1 gene. However, further research maybe needful the strategic to explore the agent of the cause of NS CPO.

\section{ACKNOWLEDGMENTS}

The authors are grateful to Indonesian Cleft Lip and Palate Foundation: Yayasan Pembina Penderita Celah Bibir dan Langit-langit (YPPCBL) in Bandung Indonesia.

\section{CONFLICTS OF INTEREST}

The authors declare that there is no conflict of interest.

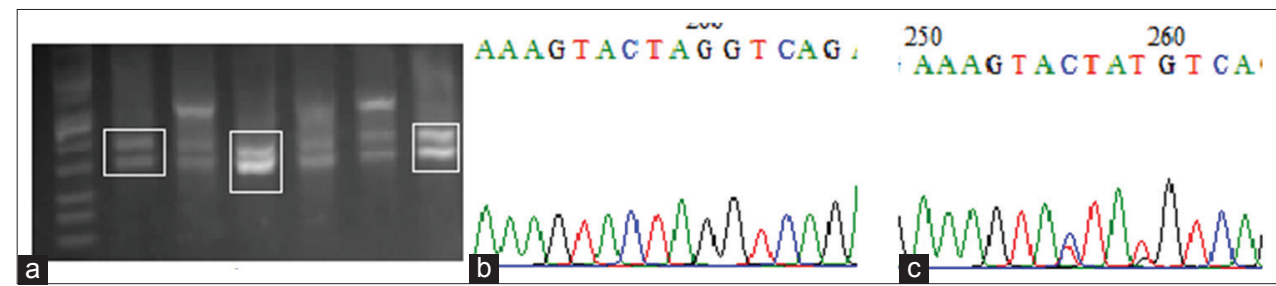

Fig. 3: (A) Polymerase chain reaction products of TGFA RsaI gene after restriction with RsaI. Line 1100 bp ladder Line 2, 4, 7. The bands in the electrophoresis appearance show digested product of $R s a$ restriction enzyme ( 2 bands at 373 and 284 bp), mean as B2B2 homozygous normal genotype. Line 3,5,6. B1B2 heterozygous mutant genotype (3 bands of 657, 373, and 284 bp. (b) Sequencing result from TGF/RsaI gene variant. The arrow show B2B2 (base of C) homozygous normal genotype. (c) Sequencing result from TGFA RsaI gene variant. The arrow show B1B2 (base of $\mathrm{C}$ and $\mathrm{T}$ ) heterozygous mutant genotype 


\section{AUTHORS CONTRIBUTIONS}

AMM carried out the conception, DNA extraction and PCR analyses also drafted the manuscript. Solid lipid nanoparticles, proprioceptive neuromuscular facilitation, and ESSS have been given the research ideas and design of research. BAG has arranged the manuscript, statistical analysis, and corresponding author. All of the authors were read and approved the final manuscript.

\section{REFERENCES}

1. Dixon MJ, Marazita ML, Beaty TH, Murray JC. Cleft lip and palate: Understanding genetic and environmental influences. Nat Rev Genet 2011;12:167-78.

2. Kim J, Langlois PH, Herdt-Losavio ML, Agopian AJ. A case-control study of maternal occupation and the risk of orofacial clefts. J Occup Environ Med 2016;58:833-9.

3. Nasroen SL, Tajrin A, Fauziah PN, Maskoen AM, Soemantri ES, Soedjana $\mathrm{H}$, et al. TGFß3/sfaN1 gene variant and the risk factor of nonsyndromic cleft palate only among Indonesian patients. Cell Mol Biol (Noisy-le-grand) 2017;63:88-91

4. Iwata J, Parada $\mathrm{C}$, Chai Y. The mechanism of TGF- $\beta$ signaling during palate development. Oral Dis 2011;17:733-44.

5. Setó-Salvia N, Stanier P. Genetics of cleft lip and/or cleft palate: Association with other common anomalies. Eur J Med Genet 2014;57:381-93

6. El-Din EY, Omar AR. Effect of prenatal administration of therapeutic dose of topiramate on placentae albino rats' fetuses. Int J Pharm Pharm Sci 2017;9:54-9.

7. Kho JV, Chu SS, Dalluma RM, Omar SZ. Medications used by pregnant women: Any safety concerns? Int J Pharm Pharm Sci 2017;9:100-6.

8. CoxTC. Taking it to the max: The genetic and developmental mechanisms coordinating midfacial morphogenesis and dysmorphology. Clin Genet 2004;65:163-76

9. Jugessur A, Murray JC. Orofacial clefting: Recent insights into a complex trait. Curr Opin Genet Dev 2005;15:270-8.

10. Ebadifar A, Hamedi R, Khorram Khorshid HR, Saliminejad K, Kamali K, Aghakhani Moghadam F, et al. Association of transforming growth factor alpha polymorphisms with nonsyndromic cleft lip and palate in Iranian population. Avicenna J Med Biotechnol 2015;7:16872.

11. Machida J, Yoshiura K, Funkhauser CD, Natsume N, Kawai T, Murray JC. Transforming Growth Factor- (TGFA): Genomic structure, boundary sequences, and mutations analysis in nonsyndromic cleft lip/ palate and cleft palate only. Genomics 1999;61:237-42.

12. Bagheri F, Ebadifar A, Khorram Khorshid HR, Kamali K. Association study of transforming growth factor alpha TaqI polymorphism and the risk of cleft lip and/or palate in an Iranian population. Birth Defects Res 2017:109:1386-9.

13. Vemuri PK, Sagi H, Dasari S, Prabhala MS, Vbs HM, Anumala LA.
Comparative study on various methods for recovery of deoxyribonucleic acid from agarose gels to explore molecular diversity. Asian J Pharm Clin Res 2016;9:422-4.

14. Bachtiar BM, Bachtiar EW. Proinflammatory MG-63 cells response infection with Enterococcus faecalis cps2 evaluated by the expression of TLR-2, IL-1 $\beta$, and iNOS mRNA. BMC Res Notes 2017;10:401.

15. Omran R, Al-Naji AH, Al-Sherify A. Investigation of Helicobacter pylori virulence genotype in gastric biopsies by polymerase chain reaction. Asian J Pharm Clin Res 2016;9:106-14

16. Stuppia L, Capogreco M, Marzo G, La Rovere D, Antonucci I, Gatta V, et al. Genetics of syndromic and nonsyndromic cleft lip and palate. J Craniofac Surg 2011;22:1722-6.

17. Gritli-Linde A. Molecular control of secondary palate development. Dev Biol 2007;301:309-26.

18. Qian JF, Feingold J, Stoll C, May E. Transforming growth factor-alpha: Characterization of the bamHI, rsaI, and taqI polymorphic regions. Am J Hum Genet 1993:53:168-75.

19. Meng T, Shi JY, Wu M, Wang Y, Li L, Liu Y, et al. Overexpression of mouse TTF-2 gene causes cleft palate. J Cell Mol Med 2012;16:2362-8.

20. He F, Xiong W, Wang Y, Li L, Liu C, Yamagami T, et al. Epithelial Wnt/ $\beta$-catenin signaling regulates palatal shelf fusion through regulation of TgfB3 expression. Dev Biol 2011;350:511-9.

21. Zhang X, Siclari VA, Lan S, Zhu J, Koyama E, Dupuis HL. The critical role of the epidermal growth factor receptor in endochondral ossification. J Bone Miner Res 2011;26:2622-33.

22. Feng C, Zhang E, Duan W, Xu Z, Zhang Y, Lu L, et al. Association between polymorphism of TGFA Taq I and cleft lip and/or palate: A meta-analysis. BMC Oral Health 2014;14:88.

23. Jugessur A, Lie RT, Wilcox AJ, Murray JC, Taylor JA, Saugstad OD, et al. Variants of developmental genes (TGFA, TGFB3, and MSX1) and their associations with orofacial clefts: A case-parent triad analysis. Genet Epidemiol 2003;24:230-9.

24. Lu XC, Yu W, Tao Y, Zhao PL, Li K, Tang LJ, et al. Contribution of transforming growth factor $\alpha$ polymorphisms to nonsyndromic orofacial clefts: A HuGE review and meta-analysis. Am J Epidemiol 2014:179:267-81

25. Stoll C, Qian JF, Feingold J, Sauvage P, May E. Genetic variation in transforming growth factor alpha: Possible association of bamHI polymorphism with bilateral sporadic cleft lip and palate. Hum Genet 1993;92:81-2

26. Chenevix-Trench G, Jones K, Green A, Martin N. Further evidence for an association between genetic variation in transforming growth factor alpha and cleft lip and palate. Am J Hum Genet 1991;48:1012-3.

27. Shiang R, Lidral AC, Ardinger HH, Buetow KH, Romitti PA, Munger RG, et al. Association of transforming growth-factor alpha gene polymorphisms with nonsyndromic cleft palate only (CPO). Am J Hum Genet 1993;53:836-43.

28. Field LL, Ray AK, Marazita ML. Transforming growth factor alpha: A modifying locus for nonsyndromic cleft lip with or without cleft palate? Eur J Hum Genet 1994;2:159-65. 